\title{
ВЕКТОРИ ЗАБЕЗПЕЧЕННЯ ОХОРОНИ ЛІКАРСЬКОЇ ТАЕМНИЦІ ПІД ЧАС КРИМІНАЛЬНОГО ПРОВАДЖЕННЯ
}

\begin{abstract}
КАНЦІР Володимир Степанович - доктор юридичних наук, професор, професор кафедри кримінального права і процесу Навчально-наукового інститут права, психології та інноваційної освіти Національного університету «Львівська політехніка»
\end{abstract}

ORCID ID: 0000-0002-3689-4697

КУШПІТ Володимир Петрович - кандидат юридичних наук, доцент, доцент кафедри кримінального права і процесу Навчально-наукового інститут права, психології та інноваційної освіти Національного університету «Львівська політехніка»

ORCID ID: 0000-0002-1664-6696

ЦИЛЮРИК Інна Ігорівна - кандидат юридичних наук, асистент кафедри кримінального права і процесу Навчально-наукового інституту права, психології та інноваційної освіти Національного університету «Львівська політехніка»

ORCID ID: 0000-0002-4776-2278

DOI 10.32782/EP.2021.2.11

\begin{abstract}
У статті проводиться аналіз законодавчого інституту, який покликаний захищати законні права та інтереси особи, пробесійной таємнииі, різновидом якоӥвиступає лікарсъка таємниия. Доводиться теза про законодавче закріплення обов'язку зберігати лікарсъку таємницю як з погляду прав пацієнтів, так $i$ в інтересах тих хворих, які з мотивів побоювання розголошення таємниці, не наважуються довіритися лікареві.
\end{abstract}

Визначено, що КПК Украӥни не містить повної заборони на розголошення лікарськой таємниці. Констатовано, що після відображення в матеріалах кримінального провадження інбормащї, що становить лікарську таємницю, дізнавач, слідчий повинен вжити всіх передбачених прочесуальним законом заходів, щоб не допустити ї розголошення. Для иъого необхідно звернутися до засади недопустимості розголошення відомостей досудового розслідування, яка передбачена у ст. 222 КПК України.

Надано пропозииіи стосовно вдосконалення нормативних положень, у яких варто закріпити обставини, у яких, під иас кримінального провадження, можуть вико- ристовуватися (розголошуватися) відомості, що становлять лікарсъку таємницю.

Ключові слова: пробесійна таємниия, лікарсъка таємниия, недопустимості розголошення відомостей досудового розслідування, медичний праиівник, лікар.

Постановка проблеми

Одним 3 першочергових завдань держави є забезпечення прав і свобод людини та громадянина, зокрема у сфері кримінального судочинства. Згідно зі ст. 32 Конституції України, ніхто не може зазнавати втручання в його особисте і сімейне життя. Не допускається збирання, зберігання, використання та поширення конфіденційної інформації про особу без іiї згоди, крім випадків, визначених законом, і лише в інтересах національної безпеки, економічного добробуту та прав людини.

Законодавчим інститутом, що покликаний захищати законні права та інтереси особи, є професійна таємниця, різновидом якої виступає лікарська таємниця. Охорона професійних таємниць у кримінальному процесі передбачає особливий порядок зберігання, розкриття та використання конфіденційної інформації під час досудо- 


\section{Кримінальне право, кримінальний процес та криміналістика}

вого провадження та судового розгляду. Водночас, повідомлення слідчому або суду відомостей, що становлять лікарську таємницю, нерідко має вирішальне значення для повного, всебічного та об'єктивного розслідування кримінальних проваджень про вбивства, згвалтування, зараження небезпечними хворобами тощо, а також виконання інших завдань кримінального судочинства.

\section{Стан дослідження проблеми}

Окремі кримінальні процесуальні аспекти охорони особистих і професійних таємниць вивчали проф. М.С. Алексєєв,О.Д. Бойков, Д.О. Гетманцев, В.С. Гулієв, Н.М. Когут, А.Ф. Коні, В.В. Король, В.Г. Мепаришвілі, I.Л. Петрухин, Ф.М. Рудинський, І.В. Смолькова, Ю.І. Стецовський, Н.В. Устименко, В.В. Юсупув та ін.

\section{Мета і завдання дослідження}

Аналіз слідчої практики свідчить, що розголошення лікарської таємниці може призвести до негативних наслідків як для провадження загалом, так і для окремих його учасників, зокрема. Ці наслідки можуть виявлятись у можливій протидії розслідуванню з боку зацікавлених осіб, неправомірному впливі на потерпілих та свідків, приховуванні та знищенні слідів кримінального правопорушення, ухиленні від слідства осіб, які причетні до кримінального правопорушення, наданні завідомо неправдивої інформації.

\section{Виклад основного матеріалу дослі- дження 3 обгрунтуванням отриманих результатів}

Лікарська таємниця посідає належне місце серед професійних таємниць. Відповідно до змісту ст. 40 Основ законодавства України про охорону здоров'я, можна зробити таке визначення лікарської таємниці [1]. Лікарська таємниця - це відомості, які не підлягають розголошенню про хворобу, медичне обстеження, огляд та їх результати, інтимну і сімейну сторони життя громадянина. На наш погляд, слушною є думка проф. С. Аихової, що відомості, які становлять лікарську таємницю, варто тлумачити більш широко і включати до них будь-яку інформацію про пацієнта [2].

ᄉікарська таємниця належить до одного 3 видів професійної таємниці та є самостійним видом конфіденційної інформації. Законодавче закріплення обов'язку зберігати лікарську таємницю, як правильно зазначає С.Я. Улицький, важливе як $з$ погляду прав пацієнтів, так і в інтересах тих хворих, які не наважуються 3 побоювання розголошення таємниці довіритися лікареві і звертаються до людей, далеких від медицини [3].

Лікарська таємниця з'явилась і тривалий час існувала як абсолютна, тобто не траплялося жодних випадків, внаслідок яких іiї можна було розголошувати. Це була таємниця від держави, а саме від правоохоронних органів, суду, а також і від близьких хворому осіб. Якщо особа звернулась до лікаря за допомогою, тобто довірилась йому, то він не мав права відмовити їй у наданні медичної допомоги й видати хворого поліції, суду.

Розголошення лікарської таємниці - це протиправне розголошення відомостей, що становлять лікарську таємницю, медичним або іншим працівником, який дізнався ïx у зв’язку з виконанням професійних або службових обов'язків, внаслідок чого ці відомості стали здобутком сторонніх осіб.

КПК України не містить повної заборони на розголошення лікарської таємниці. Відповідно до п. 4 ч. 2 ст. 65 КПК України, до осіб, які не можуть бути допитані як свідки, віднесено медичних працівників та інших осіб, яким у зв'язку з виконанням професійних обов'язків стало відомо про хворобу, медичне обстеження, огляд та їх результати, інтимну і сімейну сторони життя особи - про відомості, які становлять лікарську таємницю [4].

Повідомлення органам досудового розслідування чи суду відомостей, що становлять лікарську таємницю, може мати значення для правильного вирішення кримінального провадження. На думку I. $\mathcal{~}$. Петрухина, до таких випадків належать справи про зараження венеричною хворобою; справи, у яких виникла необхідність вирішити питання про осудність обвинуваченого або 
психічну здатність свідків і потерпілого давати показання; справи про вбивства, тілесні ушкодження, згвалтування та інші [5].

Як зазначає Г. Чеботарьова, аналіз законодавства свідчить, що лікарською таємницею є відомості про хворобу, іiі лікування, інтимне та сімейне життя особи. Саме тому важливо відмежовувати в практичній діяльності лікарську таємницю від інших відомостей про особу, що стають відомі суб’єкту, який діє у сфері медичної діяльності.

Заздалегідь дуже складно закріпити на нормативному рівні вичерпний перелік такої інформації, а тому при вирішенні цього питання в кожному конкретному випадку необхідно визначати зміст понять : «хвороба», «медичне обстеження», «медичний огляд", «результати медичного обстеження», «результати медичного огляду», «інтимна сторона життя», «сімейна сторона життя». Тому складові елементи лікарської таємниці, здебільшого, мають оцінювальний характер.

Відомості, що становлять лікарську таємницю, можна поділити на два види: медичні та інформацію про особисте і сімейне життя хворого, отриману в процесі виконання медичних обов'язків.

Останню групу інформації можна отримати як від самого хворого, так і під час надання медичної допомоги в його помешканні, через що вона набуває особистісного характеру.

Якщо проведення медичного обстеження, встановлення діагнозу хвороби, стадії перебігу, прогнозування іï розвитку, вибір методів лікування та реабілітації хворого становитимуть основний зміст медичної допомоги і фактично здійснюються самим лікарем, то інформація про особисте життя хворого може бути корисною у його лікуванні. Для прикладу, якщо особа потрапила у медичний заклад з ознаками отруєння, зізналась лікарю, що намагалась покінчити життя самогубством і тому вжила надмірну дозу снодійного. Така інформація значно полегшить роботу лікаря. Однак, ï розголошення може завдати істотної шкоди самій особі в подальшому. Навіть якщо в подальшому буде порушено кримінальне провадження за ст. 120 КК України, то лікар, як свідок, у цьому разі повинен надати слідчому чи суду інформацію винятково медичного характеру: встановлений діагноз, методи лікування, стан хворого в даний період, але не відомості про спробу самогубства, надані самим пацієнтом.

Саме тому ми поділяємо думку В.В. Коро^я, що особи, зазначені в ч. 1 ст. 40 Основ законодавства України про охорону здоров’я, можуть бути допитані як свідки тільки про характер хвороби та ії лікування, але категорично слід заборонити допитувати їх про особисте і сімейне життя хворого [6].

Медичний працівник, який володіє лікарською таємницею, може повідомити про неї на вимогу органів досудового розслідування і суду лише за наявності певних юридичних та фактичних підстав. Юридичними підставами є: факт порушення кримінального провадження; протокол складений слідчим, прокурором під час огляду медичної документації, що містить лікарську таємницю (історія хвороби пацієнта, амбулаторні картки). Фактичні підстави: медичні відомості, яких вимагають, повинні стосуватися предмета доказування у кримінальному провадженні; відомості за своїм характером мають бути такими, що їх неповідомлення компетентними органами може поставити під загрозу досягнення цілей кримінального судочинства; відомості про осіб, які не є підозрюваними, обвинуваченими, можна повідомляти лише за наявності небезпеки поширення інфекційного захворювання або при ясно вираженій згоді зацікавленої особи на їх розголос [7].

Після відображення в матеріалах кримінального провадження інформації, що становить лікарську таємницю, слідчий повинен вжити всіх передбачених процесуальним законом заходів, щоб не допустити іiі розголошення. Для цього необхідно звернутися до засади недопустимості розголошення відомостей досудового розслідування, яка передбачена у ст. 222 КПК України.

В Україні лікарська таємниця регулюється низкою нормативно-правових актів. Так, зокрема, ч. 2 ст. 32 та ч. 3 ст. 34 Конституції України передбачають, що лікар- 


\section{Кримінальне право, кримінальний процес та криміналістика}

ська таємниця може бути розголошена без згоди особи чи ії законних представників в інтересах національної безпеки, економічного добробуту й прав людини та в інтересах національної безпеки, територіальної цілісності або громадянського порядку, а також з метою запобігання заворушенням чи злочинам, для охорони здоров'я населення, для захисту репутації або прав інших людей,для запобігання розголошенню інформації, отриманої конфіденційно, або для підтримання авторитету й неупередженості правосуддя [8].

Інші законодавчі акти у сфері охорони здоров'я також конкретизують перелік відомостей, які становлять зміст лікарської таємниці. Так, законодавством визначено, що дані про перенесені та наявні хвороби в особи, яка виявила бажання здати кров або їі компоненти, а також про вживання нею наркотичних речовин та властиві їй інші форми ризикованої поведінки, що можуть сприяти зараженню донором інфекційними хворобами, які передаються через кров, і за наявності яких виконання донорської функції може бути обмежено, становлять лікарську таємницю. Крім того, до лікарської таємниці віднесено дані про реципієнтів донорських органів: осіб, які заявили свою згоду або незгоду стати донорами в разі власної смерті; стан здоров’ я людини; історію їі хвороби; мету запропонованих досліджень і лікувальних заходів; прогноз можливого розвитку захворювання, які лікар зобов'язаний надати на вимогу пацієнта, членів його сім'ї або законних представників, за винятком випадків, коли така повна інформація може завдати шкоди здоров'ю пацієнту [9].

Статтею 46 Закону України «Про інформацію» передбачено, що не підлягають розголошенню відомості, які стосуються лікарської таємниці [10].

Окрім того, ст. 30 Сімейного кодексу України встановлює обов'язок наречених повідомити один одного про стан здоров' я. При цьому, держава забезпечує створення умов для медичного обстеження наречених, а результати такого обстеження $є$ таємницею й повідомляються лише нареченим [11]. Ч. 5 згадуваної статті вводить у законодавство додаткову підставу для визнання шлюбу недійсним: у разі приховування відомостей про стан здоров'я одним iз наречених, наслідком чого може стати (стало) порушення фізичного або психічного здоров'я іншого нареченого чи їх нащадків.

Ч. 1 ст. 7 Закону України «Про захист персональних даних» забороняє обробку персональних даних про расове або етнічне походження, політичні, релігійні або світоглядні переконання, членство в політичних партіях та професійних спілках, засуджених до кримінального покарання, а також даних, що стосуються здоров'я, статевого життя, біометричних або генетичних даних. Положення частини першої цієї статті не застосовується, якщо обробка персональних даних необхідна в цілях охорони здоров'я, встановлення медичного діагнозу, для забезпечення піклування чи лікування або надання медичних послуг за умови, що такі дані обробляються медичним працівником або іншою особою закладу охорони здоров'я, на якого покладено обов'язок щодо забезпечення захисту персональних даних та на якого поширюється законодавство про лікарську таємницю.

Невідпрацьованим залишається механізм фіксації волевиявлення пацієнта щодо надання дозволу на обробку його персональних даних. Питання також можуть виникнути на практиці під час застосування положень Закону України «Про захист персональних даних»у процесі інформування та зберігання інформації про неповнолітніх і малолітніх пацієнтів.

Вважаємо, що мету обробки персональних даних має бути сформульовано в законах, інших нормативно-правових актах, положеннях, установчих чи інших документах, які регулюють діяльність володільця бази персональних даних, у тому числі й керівників медичних установ, та відповідати законодавству про захист персональних даних. У разі зміни визначеної мети обробки персональних даних суб'єктом персональних даних має бути надано згоду на обробку його даних відповідно до зміненої мети. 
Усі випускники відповідних спеціалізованих закладів вищої освіти приймають «Клятву лікаря», що затверджена Указом Президента України від 15 червня 1992 року, № 349. У ній також зазначено про зберігання лікарської таємниці та невикористовування ії на шкоду людині. Аналіз цього акту свідчить, що у ньому вміщено всі важливі норми етики й деонтологічні принципи, якими в подальшому повинні користуватися медичні працівники, також враховано й міжнародну практику.

Відомості, що становлять лікарську таємницю, можуть бути розголошені різним форматом: повідомлення в бесіді, у виступі, у приватному листі, у доповіді, ознайомлення сторонніх осіб із записами в історії хвороби або амбулаторній картці, опублікування відомостей без зміни прізвища хворого у відкритих наукових працях. Розголошенням лікарської таємниці варто вважати й ті випадки, коли відомості стали відомі хоча 6 одній сторонній особі.

Додержання лікарської таємниці є прямим обов'язком медичних працівників, за iii незаконне розголошення встановлено кримінальну відповідальність (ст. 145 КК України) [4].

До суб'єктів - носіїв лікарської таємниці може бути віднесено не тільки лікарів, а й інших працівників медичних установ, які при виконанні своїх службових обов'язків можуть стати власниками відомостей, що становлять, згідно 3 чинним законодавством, лікарську таємницю.

Згідно з вітчизняним законодавством, лікар є особою, яка може виступати як свідок лише за певних умов. 3 приводу обставин, які стали відомі лікарю чи були йому довірені у зв'язку з виконанням професійних обов'язків, він може бути допитаний лише тоді, коли особа, яка довірила такі відомості, згідна на їх розголошення під час допиту. Така згода має бути оформлена в письмовому вигляді й долучена до матеріалів кримінального провадження.

Обов'язок слідчого - до початку допиту роз'яснити лікарю право відмовитися давати показання з приводу обставин, які стали відомі йому у зв'язку зі здійсненням професійної діяльності. Роз'яснення прав, згоду на допит чи відмову від допиту має бути відображено у протоколі допиту. Такий протокол має бути складений і в такому випадку, коли особа відмовляється давати показання.

Під час розслідування кримінального провадження, дізнавач, слідчий, прокурор, суд, суддя в силу своїх службових і професійних обов'язків можуть ознайомлюватися 3 конфіденційною інформацією про особу, в тому числі і з інформацією, що становить лікарську таємницю.

У цьому разі діяльність дізнавача, слідчого 3 розслідування кримінальних проваджень, пов’язаних 3 лікарською таємницею, є складним соціально значущим різновидом державної діяльності, що пов'язаний з обмеженням сфери особистих прав і свобод громадян. Саме правові, морально-етичні норми регламентують і регулюють взаємостосунки між учасниками кримінального процесу.

\section{Висновки}

Таким чином, до суб'єктів, яким можуть стати відомі відомості, що становлять лікарську таємницю, з одного боку, належать медичні працівники, з іншого - службові особи кримінального провадження (дізнавач, слідчий, прокурор, суддя). Отже, необхідно окремим нормативним актом закріпити, за яких обставин вищезазначені особи під час кримінального провадження можуть розголошувати відомості, що становлять лікарську таємницю.

\section{Мітература}

1. Основи законодавства України про охорону здоров'я: чинне законодавство зі змінами та доповненнями. URL:https:// zakon.rada.gov.ua/laws/show/2801-12\#Text.

2. Лихова С. Конфіденційна інформація як об'єкт кримінально-правової охорони. Прокуратура. Аюдина. Держава. 2005.№ 4. C.49.

3. Улицкий С. Я. Обязанность сохранять врачебную тайну. Сочиалистическая законность. 1971. № 1. С.39.

4. Кримінальний кодекс України: Закон України від 5 квітня 2001 року 


\section{Кримінальне право, кримінальний процес та криміналістика}

№ 2341-III. URL: https://zakon.rada.gov.ua/ laws/show/2341-14\#Text.

5. Кримінальний процесуальний кодекс України: Закон України від 13.04.2012. URL: https://zakon.rada.gov.ua/ laws/show/4651-17\#Text.

6. Король В. В. Засада гласності кримінального судочинства України: зняття, зміст, підстави, обмеження. Івано-Франківськ, 2003. С. 114.

7. Мепаришвили Г. Д. Врачебная тайна и уголовное судопроизводство. Советское государство и право. 1989. № 11. С. 76-77.

8. Конституція України: прийнята Верховною Радою України 28 червня 1996. URL: http://zakon5.rada.gov.ua.

9. Цивільний кодекс України: Закон України від 16 січня 2003 року№ 435-IV. URL: https://zakon.rada.gov.ua/ laws/show/435-15\#Text.

10. Про інформацію: Закон України від 2 жовтня 1992. № 2657-XII. URL: https:// zakon.rada.gov.ua/laws/show/2657-12\#Text.

11. Сімейний кодекс України: Закон України від 10 січня 2002. № 2947-III. URL: https://zakon.rada.gov.ua/laws/show/294714\#Text.
The article analyzes the legislative institute, which is designed to protect the legitimate rights and interests of the person, professional secrecy, a kind of which is medical secrecy. It is argued that the obligation to maintain medical secrecy is enshrined in law, both in terms of patients' rights and in the interests of those patients who, for reasons of fear of disclosure, do not dare to trust a doctor.

It is determined that the CPC of Ukraine does not contain a complete ban on the disclosure of medical secrets. It is stated that after the information constituting a medical secret is reflected in the materials of the criminal proceedings, the investigator and investigator must take all measures provided by the procedural law to prevent its disclosure. For this purpose it is necessary to address the principle of inadmissibility of disclosure of information of pretrial investigation which is provided in Art. 222 of the Criminal Procedure Code of Ukraine.

Proposals have been made to improve the regulations in which it is necessary to enshrine the circumstances in which, during criminal proceedings, information that constitutes medical secrecy may be used (disclosed).

Key words: professional secrecy, medical secrecy, inadmissibility of disclosure of pre-trial investigation information, medical worker, doctor. 